\title{
NAJPOVOLJNIJI OBLIK OSI LUČNOG MOSTA
}

\author{
Bonislav Grgić, univ.bacc.ing.aedif. \\ Sveučilište Josipa Jurja Strossmayera u Osijeku, Građevinski fakultet Osijek, student \\ Mario Jeleč, univ.bacc.ing.aedif. \\ Sveučilište Josipa Jurja Strossmayera u Osijeku, Građevinski fakultet Osijek, student \\ Ivan Kraus, mag.ing.aedif. \\ Sveučilište Josipa Jurja Strossmayera u Osijeku, Građevinski fakultet Osijek \\ Hrvoje Draganić, dipl.ing.građ. \\ Sveučilište Josipa Jurja Strossmayera u Osijeku, Građevinski fakultet Osijek
}

Sažetak: Predstavljen je proračun najpovoljnijeg oblika osi luka mosta, koristeći uvjet da moment savijanja od stalnog opterećenja iščezava u svim presjecima. Za danu geometriju prepreke proračunani su oblici luka za različite visine strjelice luka. Nakon toga određene su rezne sile i reakcije u potporama pomoću kojih je određena najpovoljnija strjelica luka i pripadni oblik. Rezne sile su proračunane na štapnom modelu luka koristeći programski paket SAP2000. Opterećenje koje je uzeto u obzir je vlastita težina rasponske konstrukcije koja je pretpostavljena kao rebrasti presjek s pripadnom opremom mosta (ograda, vijenac, pješački hodnik, rubnjak, slojevi kolnika), težina nadlučnih stupova i luka čiji je oblik pretpostavljen kao šuplji pravokutni presjek. Prometno opterećenje i ostala opterećenja ne ulaze u početni proračun, već se koriste u daljnjem proračunu luka na temelju čega se vrše dodatne ispravke oblika.

Ključne riječi: lučni most, oblik luka, numerički model

\section{OPTIMUM AXIS FORM OF THE ARCH BRIDGE}

\begin{abstract}
Calculation of the optimum axis shape of the arch bridge is presented using a condition which implies that the bending moment due to dead load is equal to zero in every all arch sections. For a given geometry of the obstacle different types of arch shapes for different arch elevations were calculated. After that, internal forces in the arch and supports forces were calculated by which optimum shape of the arch is determined. Forces were determined on the beam model of the arch using software package SAP2000. The load taken into account was a self-weight of the superstructure that is assumed as a ribbed cross-section with adequate bridge equipment (guard rail, facia, footway, curb, and roadway) and self-weight of arch and arch columns which are assumed to be of a hollow rectangular cross-section. Traffic and other loads didn't taken into account in preliminary calculations but they are used in further design and based on them axis form is corrected.
\end{abstract}

Keywords: arch shape, arch bridge, numerical model 


\section{Uvod}

Reakcije u osloncima grednih nosača opterećenih vertikalnim, jednoliko rasprostrtim opterećenjem su vertikalne. Zakrivljujući gredu u konveksan oblik, oblikujući luk, u luku opterećenom vertikalnim, jednoliko rasprostrtim opterećenjem nastaje tlačna sila, a u osloncima su reakcije kose (mogu se prikazati horizontalnom i vertikalnom komponentom). Moment savijanja u luku se smanjuje u odnosu na jednako opterećenu gredu, a u idealnom slučaju, kada se os luka poklapa s potpornom krivuljom, čak iščezava. Kako se u luku od vertikalnog opterećenja javljaju mali momenti savijanja i velika uzdužna tlačna sila, iskorištava se glavna prednost betona kao gradiva, a to je visoka tlačna čvrstoća. Os luka se oblikuje po tzv. potpornoj krivulji, no odstupanja od nje su neizbježna zbog elastičnog skraćenja luka, ali i dugotrajnih izobličenja te toplinskih djelovanja. Nastala odstupanja je djelomično moguće nadoknaditi nadvišenjima pri izvedbi.

Kako je prethodno napomenuto, glavna prednost betonskog luka je velika tlačna čvrstoća pa tako velika učinkovitost luka potječe od iskorištenosti presjeka u kojemu prevladava tlak. Ovo je moguće samo ako postoji visoki stupanj punoće plohe tlačnih naprezanja, što je moguće samo pri malim mimoosnostima tlačne sile. Također je potrebno ispuniti uvjet stabilnosti. Kako bi tlačna krivulja bila što bliža osi luka, nužna je ravnoteža s okomitim opterećenjima od vanjskog djelovanja. Iz ovoga proizlazi kako su lukovi prikladni za mostove kod kojih je stalno opterećenje dominantno, a to znači za mostove velikog raspona. Potporna krivulja za približno jednoliko raspodijeljeno vlastito opterećenje ima oblik sličan paraboli. Pri tomu se mogu pojaviti različiti omjeri strjelice i raspona luka (flL) koji proistječu iz obrisa prepreke, ali i iz uvjeta temeljenja [1]. Budući da se dio stalnog opterećenja na luk prenosi u vidu niza koncentriranih sila (nadlučni stupovi), potporna krivulja ima prekide na mjestima djelovanja koncentriranih sila.

\section{Određivanje najpovoljnijeg oblika osi luka}

Najčešći oblik osi luka betonskog mosta je veriga, odnosno verižna krivulja. Danas je taj pojam poopćen, pa tako verižnim lukom nazivamo luk čija os ne odstupa bitno od rezultantnog područja kroz koji prolaze sve tlačne (potporne) krivulje za najnepovoljnije slučajeve opterećenja [2]. Područje će biti uže što je omjer stalnog $g$ i promjenjivoga $q$ opterećenja manji i što je manji ukupni učinak nepovoljnih djelovanja (skupljanje, puzanje betona, itd.). Vlastita težina luka ovisna je o obliku potporne krivulje, ali vrijedi i obratno, stoga se ne može odrediti potporna krivulja ako nije poznato opterećenje, a opet opterećenje (vlastita težina) nije poznato ako nije poznat oblik osi luka. Iz ovoga proizlazi kako je neizbježno postupno približavanje u proračunu, odnosno postupak je iterativan: pretpostavi se oblik osi luka, zatim se izračunaju težine, pa se potom određuje potporna krivulja. Koriste se tri pretpostavke proračuna te koju god pretpostavku uzeli za proračun na kraju dobivamo približno jednak rezultat.

Osnovna diferencijalna jednadžba za slučaj nepromjenjiva poprečnoga presjeka luka čijim rješavanjem možemo doći do izraza za najpovoljniji oblik osi luka, ima sljedeći oblik:

$$
\frac{d^{2} y}{d x^{2}}=\frac{1}{H}\left\{g_{1}\left[1+\alpha \sqrt{1+\left(\frac{d y}{d x}\right)^{2}}\right]+\gamma \cdot y\right\}
$$

U nastavku se navode tri pretpostavke proračuna kojima dobivamo zatvorena rješenja jednadžbe (1).

1. pretpostavka: Težina luka i težina ispune jednaka je nuli. Koristimo ju za jednoliko rasprostrto opterećenje pa je tada progibna linija jednaka jednadžbi parabole:

$$
y=\frac{4 f}{l^{2}} \cdot x^{2}
$$

gdje su prema slici 1:

$y$ - ordinata parabole u koordinatnom sustavu 
$x$ - apscisa parabole u koordinatnom sustavu

$f$ - strjelica parabole

I- duljina parabole.

2. pretpostavka: Težina luka jednaka je nuli, tada je jednadžba parabole jednaka:

$$
y=\frac{f}{m-1} \cdot(k \cdot \operatorname{ch} \beta-1)
$$

gdje su prema slici 1:

$$
\begin{aligned}
& m=\frac{g_{k}}{g}-\text { omjer opterećenja } \\
& \beta=\frac{2 x}{l}-\text { omjer dvostruke udaljenosti promatranog mjesta na luku od vrha luka i ukupnog raspona luka } \\
& k=\ln \left(m+\sqrt{m^{2}-1}\right) \text { - koeficijent ovisan o omjeru opterećenja. }
\end{aligned}
$$

3. pretpostavka: Uzimamo u obzir samo vlastitu težinu luka, težina kolničkog sklopa i ispune jednaka je nuli, tada je jednadžba parabole jednaka:

$$
y=\frac{1}{a} \cdot[\operatorname{ch}(a x)-1]
$$

gdje su prema slici 1:

$$
a=\frac{g_{2}}{H} \text { - omjer težine luka i uzdužne sile u luku }
$$

$g_{\xi}$ - ukupna težina po jedinici duljine mosta

$g_{1}$ - težina kolničkog sklopa

$g_{2}$ - težina luka

$\gamma$ - prostorna težina ispune.

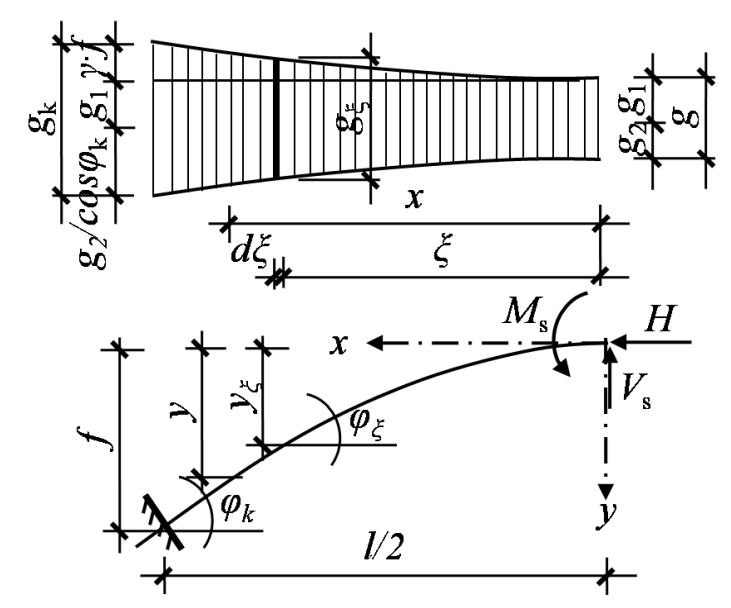

Slika 1 - Raspodjela opterećenja na luku [2]

Jednoliko rasprostrto vertikalno opterećenje je u praksi gotovo nemoguće kao slučaj opterećenja, već stvarno opterećenje čine nadlučni stupovi i projekcije težine luka na horizontalu. Ovakvo opterećenje je nad petama luka najveće, a u tjemenu najmanje, dok se između peta i tjemena mijenja po nekoj zakonitosti. 
Najpovoljniji oblik osi luka može se odrediti i iz uvjeta da moment savijanja iščezava u svim presjecima (slika 1). Na ovaj način os luka se poklapa s potpornom linijom te je u potpunosti iskorištena tlačna čvrstoća betona jer se u luku javljaju samo tlačne uzdužne sile. Uvjet ravnoteže unutarnjih sila u luku:

$$
\begin{aligned}
& H \cdot y-\int_{0}^{x}(x-\xi) \cdot g_{\xi} d \xi=0 \\
& y=\frac{1}{H} \int_{0}^{x}(x-\xi) \cdot g_{\xi} d \xi \\
& g_{\xi}=g_{1}+\frac{g_{2}}{\cos \varphi_{\xi}}+\gamma \cdot y_{\xi},
\end{aligned}
$$

Sređivanjem izraza (6) dolazimo do jednadžbe oblika osi luka:

$$
y=A x^{2}+B x^{3}+C x^{4}
$$

pri čemu su parametri:

$$
\begin{aligned}
& A=\frac{a}{2 H} ; \quad B=\frac{b}{6 H} ; \quad C=\frac{c}{12 H} ; \quad H=\frac{l^{2}}{8 f}\left(a+\frac{b l}{6}+\frac{c l^{2}}{24}\right) \\
& a=g_{1}(1+\alpha) ; \quad b=g_{1} \alpha(\omega-1) \frac{1}{l} ; \quad c=\left[2 g_{1} \alpha(\omega-1)+4 \gamma f\right] \frac{1}{l^{2}} ; \omega=\sqrt{1+\frac{16 f^{2}}{l^{2}}}
\end{aligned}
$$

Praksa je pokazala da ovi približni izrazi dovoljno točno određuju oblik verižne krivulje za ukupno stalno opterećenje. Prilikom odabira najpovoljnijeg oblika luka u radu je mijenjan omjer strjelice i raspona $f / L$ (slika 2). Omjer ne smije biti manji od 1/10 (1/12) [3], a preporučljivo je 1/5 [3], što pokazuje daljnji proračun.

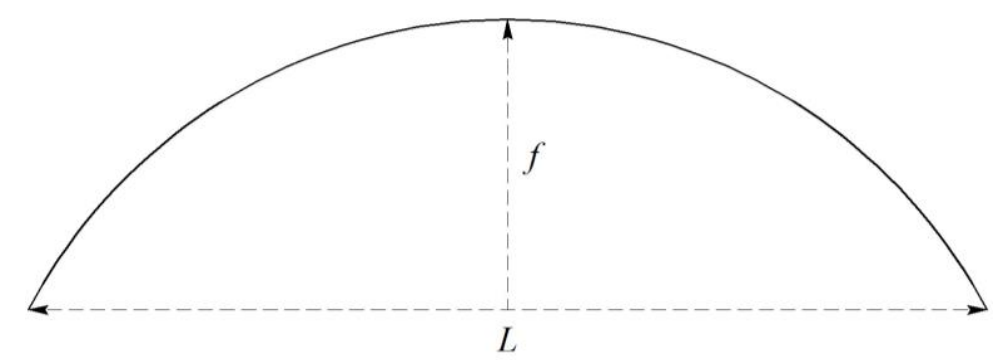

\section{Slika 2 - Geometrijske karakteristike luka}

\subsection{Opis mosta}

Analiziran je lučni most za prijelaz državne ceste preko riječne prepreke. Korito rijeke je u pravcu, okomito na os ceste. Nadlučna gredna rasponska konstrukcija ima devet polja, središnji rasponi, njih sedam, duljine su $20 \mathrm{~m}$, a krajnji rasponi duljine $13 \mathrm{~m}$, što čini ukupnu udaljenost između osi ležajeva na upornjacima $166 \mathrm{~m}$. Prednapeti rebrasti rasponski sklop nadlučne konstrukcije je kontinuirani nosač izrađen od betona razreda C40/50. Neprekidnost nadlučne rasponske konstrukcije ostvarena je povezivanjem prednapetih nosača poprečnim nosačima iznad svakog oslonca, odnosno svakog nadlučnog stupišta. Ukupna širina nadlučnog rasponskog sklopa iznosi $10 \mathrm{~m}$. Kolnički zastor se izvodi od dva sloja asfaltnog betona debljine $3 \mathrm{~cm}$ i $5 \mathrm{~cm}$ (slika 3 i tablica 1). Nadlučni stupovi su izmjera $150 \times 150 \mathrm{~cm}$, kružnog prošupljenja promjera $100 \mathrm{~cm}$. Na dnu su upeti u luk, a na vrhu u naglavnu gredu. Izrađeni su koristeći beton razreda C40/50. Nadlučna konstrukcija oslanja se preko stupišta na luk šupljeg kvadratnog poprečnog presjeka izrađenog od betona razreda C40/50. Poprečni presjek mosta prikazan je na slici 3. Elementi mosta su odabrani prema općim preporukama danim u [4] i [5]. 


\subsection{Analiza opterećenja}

Na temelju odabranih geometrijskih izmjera poprečnih presjeka rasponskog sklopa, luka i nadlučnih stupova, određene su vlastite težine koje su dalje korištene kao jedan od parametara pri određivanju najpovoljnijeg oblika osi luka.

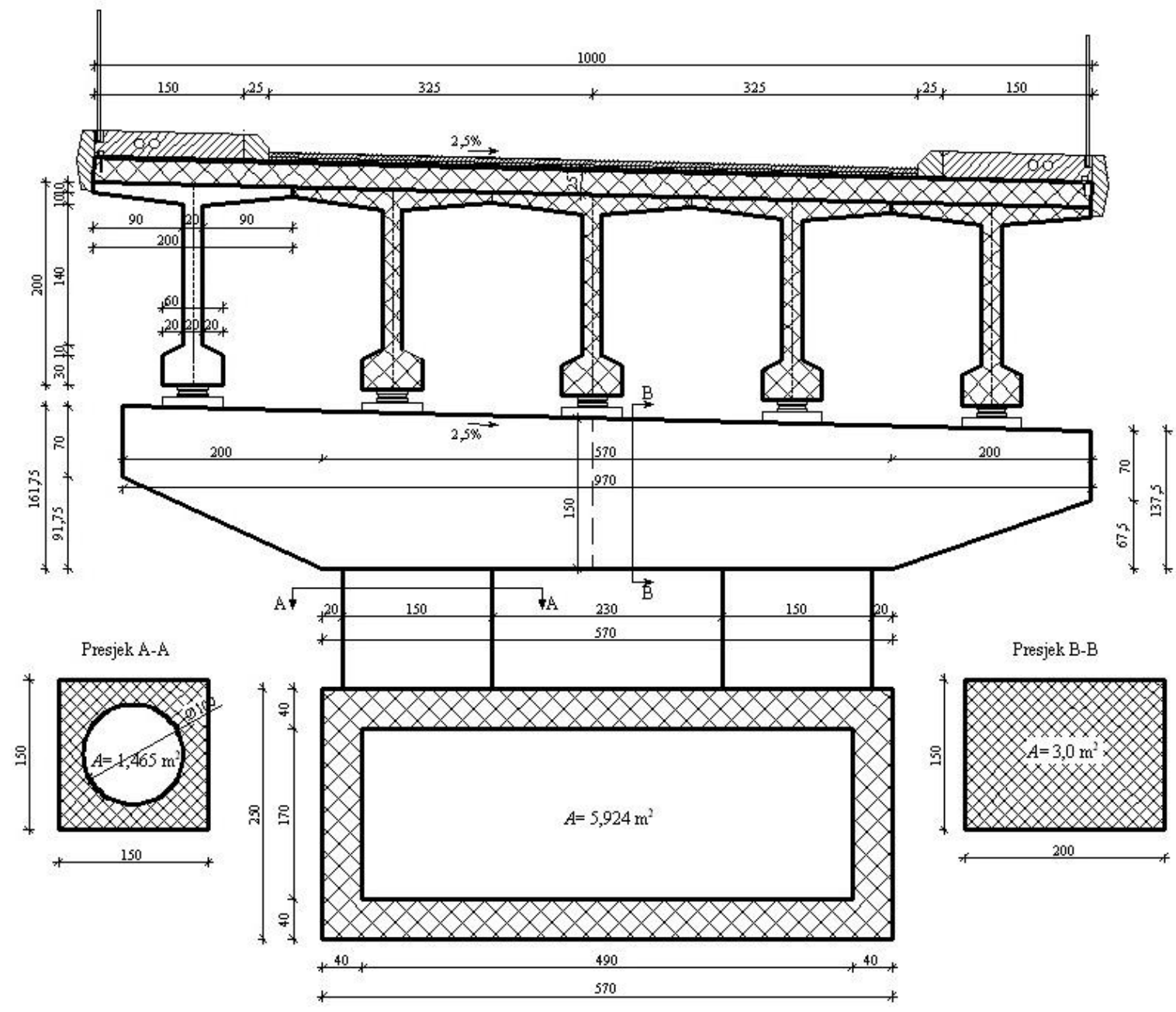

Slika 3 - Poprečni presjek rasponskog sklopa [cm]

Tablica 1 - Određivanje vlastite težine

\begin{tabular}{|l|c|}
\hline Element & Težina [kN/m] \\
\hline \hline Vlastita težina rasponskog sklopa & 163,76 \\
\hline Ograda & 1,00 \\
\hline AB vijenac & 4,35 \\
\hline Pješački hodnik & 18,75 \\
\hline Rubnjak & 2,64 \\
\hline Asfaltno-betonski zastor & 11,44 \\
\hline Hidroizolacija & 2,10 \\
\hline Ukupno & $\mathbf{2 0 4 , 0 4}$ \\
\hline \hline Vlastita težina naglavne grede & $\mathbf{6 4 6 , 1 4} \mathbf{~ k N}$ \\
\hline Vlastita težina stupa & $\mathbf{3 6 , 6 2}$ \\
\hline \hline Vlastita težina luka & $\mathbf{1 4 8 , 1 0}$ \\
\hline
\end{tabular}




\subsection{Odabir optimalne osi}

Oblici osi luka su proračunani prema izrazu (8). U tablicama 2 i 3 priložen je primjer proračuna koordinata točaka osi luka za slučaj kada je $f=20 \mathrm{~m}$.

Tablica 2 - Parametri za proračun oblika luka visine strjelice $f=20 \mathrm{~m}$

\begin{tabular}{|c|c|c|c|c|c|c|c|c|c|c|c|}
\hline$[\mathrm{m}]$ & $\begin{array}{c}f f \\
{[\mathrm{~m}]}\end{array}$ & $\begin{array}{c}g_{1} \\
{\left[\mathrm{kN} / \mathrm{m}^{\prime}\right]}\end{array}$ & $a$ & $\omega$ & a & b & c & H & A & B & C \\
\hline 100 & 20 & 204,04 & 1,0 & 1,281 & 408,080 & 0,573 & 0,091 & 28483,0 & 0,0071635711 & 0,000003350 & 0,0000002676 \\
\hline
\end{tabular}

Tablica 3 - Izračunane koordinate točaka

\begin{tabular}{|c|c|}
\hline$x[\mathrm{~m}]$ & $y[\mathrm{~m}]$ \\
\hline 0 & 0 \\
\hline 1 & 0,007167 \\
\hline 2 & 0,028685 \\
\hline 3 & 0,064584 \\
\hline 4 & 0,114900 \\
\hline 5 & 0,179675 \\
\hline 6 & 0,258959 \\
\hline 7 & 0,352807 \\
\hline 8 & 0,46128 \\
\hline 9 & 0,584447 \\
\hline 10 & 0,722383 \\
\hline 11 & 0,875169 \\
\hline 12 & 1,042892 \\
\hline 13 & 1,225646 \\
\hline 14 & 1,423532 \\
\hline 15 & 1,636657 \\
\hline 16 & 1,865133 \\
\hline 17 & 2,109080 \\
\hline
\end{tabular}

\begin{tabular}{|c|c|}
\hline $\mathbf{x}[\mathrm{m}]$ & $\mathbf{y}[\mathrm{m}]$ \\
\hline 17 & 2,109080 \\
\hline 18 & 2,368625 \\
\hline 19 & 2,643899 \\
\hline 20 & 2,935042 \\
\hline 21 & 3,242199 \\
\hline 22 & 3,565522 \\
\hline 23 & 3,905169 \\
\hline 24 & 4,261305 \\
\hline 25 & 4,634099 \\
\hline 26 & 5,02373 \\
\hline 27 & 5,43038 \\
\hline 28 & 5,85425 \\
\hline 29 & 6,29552 \\
\hline 30 & 6,75440 \\
\hline 31 & 7,23110 \\
\hline 32 & 7,72584 \\
\hline 33 & 8,23884 \\
\hline 34 & 8,77033 \\
\hline
\end{tabular}

\begin{tabular}{|c|c|}
\hline$x[\mathrm{~m}]$ & $y[\mathrm{~m}]$ \\
\hline 34 & 8,77033 \\
\hline 35 & 9,32054 \\
\hline 36 & 9,88971 \\
\hline 37 & 10,47809 \\
\hline 38 & 11,08595 \\
\hline 39 & 11,71353 \\
\hline 40 & 12,36110 \\
\hline 41 & 13,02895 \\
\hline 42 & 13,71734 \\
\hline 43 & 14,42657 \\
\hline 44 & 15,15693 \\
\hline 45 & 15,90872 \\
\hline 46 & 16,68224 \\
\hline 47 & 17,47780 \\
\hline 48 & 18,29573 \\
\hline 49 & 19,13636 \\
\hline 50 & 20,00000 \\
\hline
\end{tabular}

Dijagram dobiven iz proračuna prikazan je na slici 4. Na isti način (promjenom veličine $f$ ) dobivene su koordinate i za ostale vrijednosti visine strjelice luka $f$.

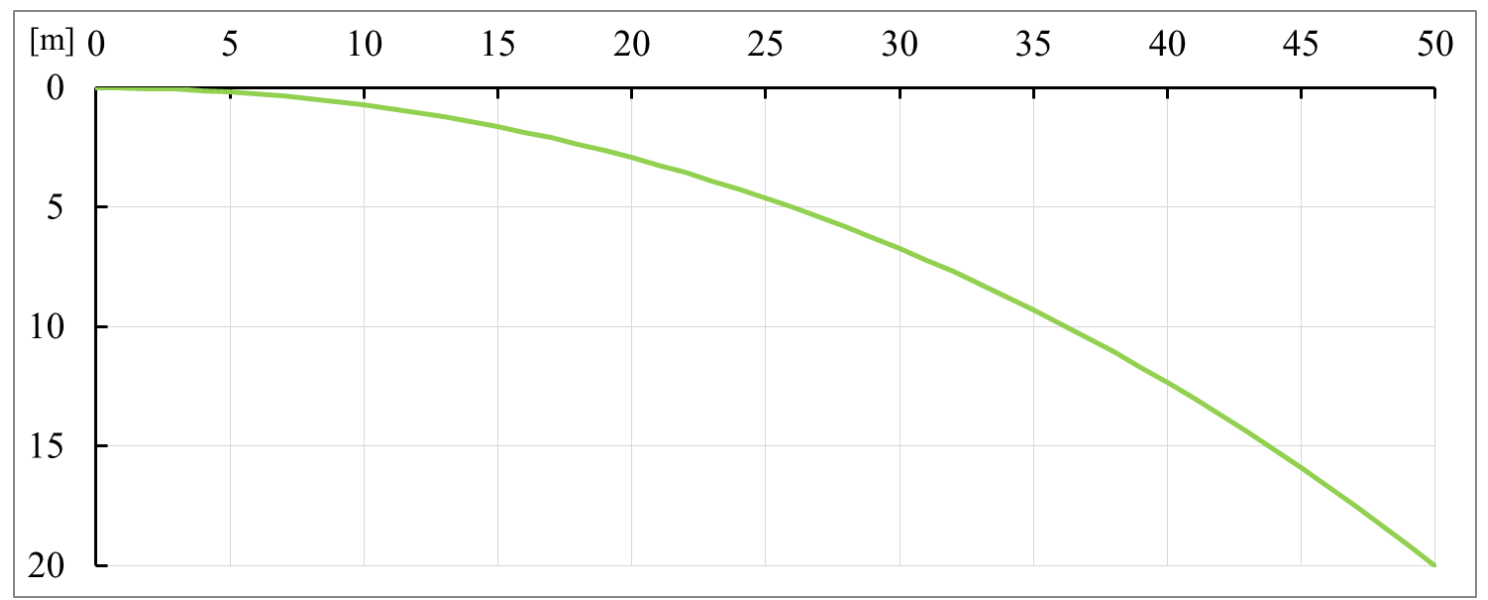

Slika 4 - Polovica luka visine strjelice $f=20 \mathrm{~m}$ 
Proračun oblika osi luka izrađen je za visine strjelice $f$ od 10 do $50 \mathrm{~m}$ u koracima od $5 \mathrm{~m}$. Dobiveni oblici za različite visine strjelice $f$ prikazani su na slici 4 . Prema slici 4 određene su duljine stupova, što je bilo potrebno za određivanje opterećenja na luk.

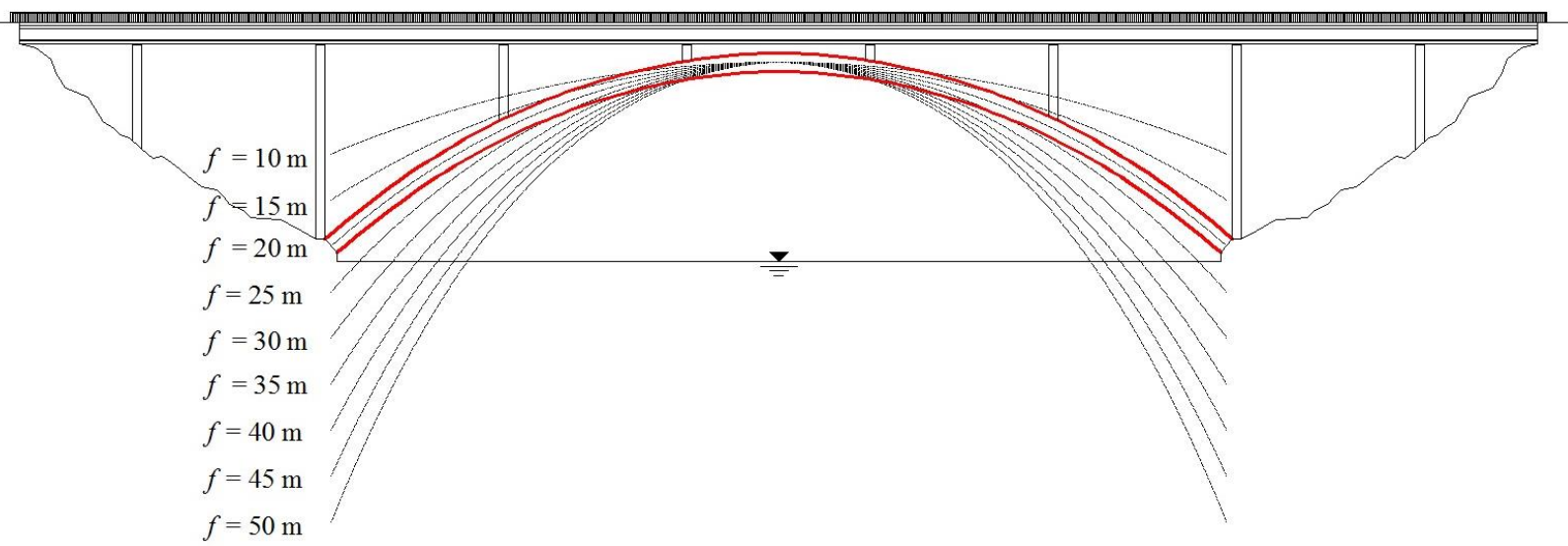

\section{Slika 5 - Oblici luka za različite visine strjelice $f$}

Koncentrirane sile koje djeluju u točkama oslanjanja stupova na luk izračunane su prema dužinama stupova te težini pripadnog dijela rasponskog sklopa (tablica 4).

Tablica 4 - Proračun koncentriranih opterećenja na luk

\begin{tabular}{|c|c|c|c|c|c|c|c|}
\hline Stup & $L[\mathrm{~m}]$ & $F_{\text {stup }}[\mathrm{kN}]$ & $\begin{array}{c}\text { Fstup +nosačcnnaglavna } \\
\text { greda }[k N]\end{array}$ & Stup & $L[\mathrm{~m}]$ & $F_{\text {stup }}[\mathrm{kN}]$ & $\begin{array}{c}F_{\text {stup }} \text { nosač }+ \text { naglavna } \\
\text { greda }\end{array}$ \\
\hline \multicolumn{4}{|l|}{$f=10$} & \multicolumn{4}{|l|}{$f=35$} \\
\hline S1 & 12,45 & 911,96 & 5638,90 & S1 & 37,45 & 2743,21 & 7470,15 \\
\hline S2 & 5,95 & 435,84 & 5162,78 & S2 & 13,67 & 1001,33 & 5728,27 \\
\hline S3 & 2,83 & 207,30 & 4934,24 & S3 & 3,61 & 264,43 & 4991,37 \\
\hline \multicolumn{4}{|l|}{$f=15$} & \multicolumn{4}{|l|}{$f=40$} \\
\hline S1 & 17,45 & 1278,21 & 6005,15 & $S 1$ & 42,45 & 3109,46 & 7836,40 \\
\hline S2 & 7,60 & 556,70 & 5283,64 & S2 & 15,07 & 1103,88 & 5830,82 \\
\hline S3 & 3,01 & 220,48 & 4947,42 & S3 & 3,73 & 273,22 & 5000,16 \\
\hline \multicolumn{4}{|l|}{$f=20$} & \multicolumn{4}{|l|}{$f=45$} \\
\hline S1 & 22,45 & 1644,46 & 6371,40 & $\mathrm{~S} 1$ & 47,45 & 3475,71 & 8202,65 \\
\hline S2 & 9,20 & 673,90 & 5400,84 & $S 2$ & 16,42 & 1202,77 & 5929,71 \\
\hline S3 & 3,17 & 232,20 & 4959,14 & S3 & 3,85 & 282,01 & 5008,95 \\
\hline \multicolumn{4}{|l|}{$f=25$} & \multicolumn{4}{|l|}{$f=50$} \\
\hline S1 & 27,45 & 2010,71 & 6737,65 & S1 & 52,45 & 3841,96 & 8568,90 \\
\hline S2 & 10,75 & 787,44 & 5514,38 & S2 & 17,74 & 1299,46 & 6026,40 \\
\hline S3 & 3,33 & 243,92 & 4970,86 & S3 & 3,97 & 290,80 & 5017,74 \\
\hline \multicolumn{4}{|l|}{$f=30$} & & & & \\
\hline S1 & 32,45 & 2376,96 & 7103,90 & & & & \\
\hline $\mathrm{S} 2$ & 12,23 & 895,85 & 5622,79 & & & & \\
\hline S3 & 3,47 & 254,18 & 4981,12 & & & & \\
\hline
\end{tabular}

Izračunane vrijednosti koncentriranih sila za sve vrijednosti strjelice luka $f$ nanesene su na luk $u$ programskom paketu SAP2000. Na slici 6 je prikazan slučaj kada je $f=20 \mathrm{~m}$. Na isti način postupak je proveden za druge iznose visine strjelice luka $f$. 


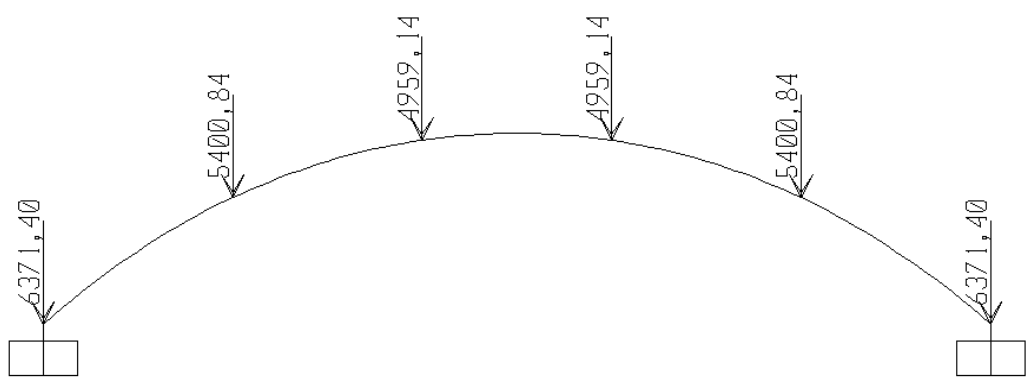

Slika 6 - Koncentrirane sile na luku [kN]

Proveden je linearno-elastični proračun reznih sila bez uzimanja u obzir nastanka pukotina i posljedično smanjenje krutosti betonskog presjeka, samo za stalno opterećenje, jer je ono ključno u preliminarnom odabiru najpovoljnijeg oblika osi luka. $\mathrm{Na}$ osnovi dobivenog oblika luka za stalno opterećenje vrše se proračuni na prometno opterećenje i potresno djelovanje te se na osnovi rezultata dodatno prilagođava oblik osi luka dok se ne dođe do najpovoljnijeg (najmanji momenti savijanja). Proračuni su vršeni za sve oblike osi luka s pripadnim koncentriranim silama od nadlučne konstrukcije i vlastite težine luka koja je automatski uzeta u obzir u programu SAP2000. Izdvojeni su rezultati pri ležaju i ispod stupa S3 (slika 7), jer se pokazalo da se na tim mjestima pojavljuju najveće vrijednosti unutarnjih sila.

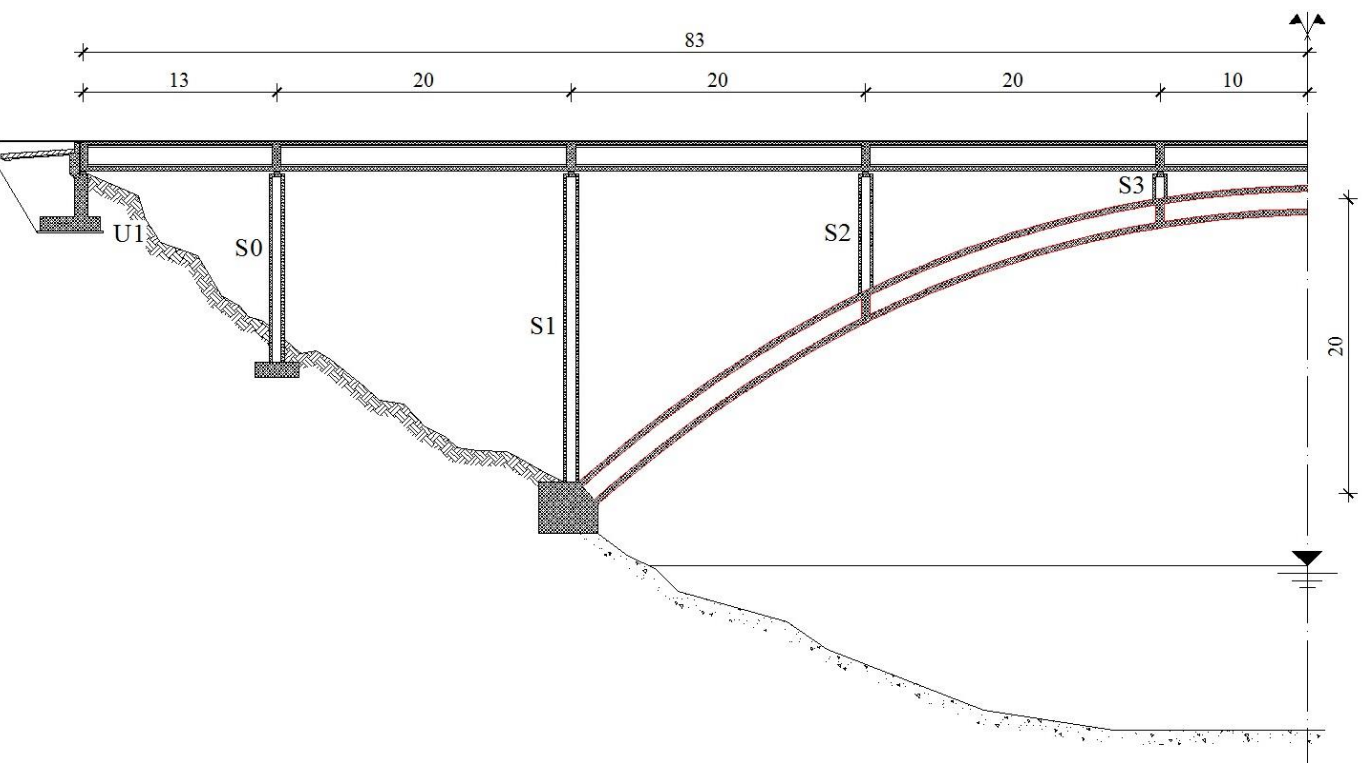

\section{Slika 7 - Oznake stupova korištene pri proračunu opterećenja [m]}

Reakcija u ležajevima, momenti savijanja i uzdužne sile u peti luka i ispod stupa S3 (slike 8, 9 i 10) su vrijednosti unutarnjih sila koje su bilježene i kasnije uspoređivane, te prema njima određen najpovoljniji oblik osi luka.

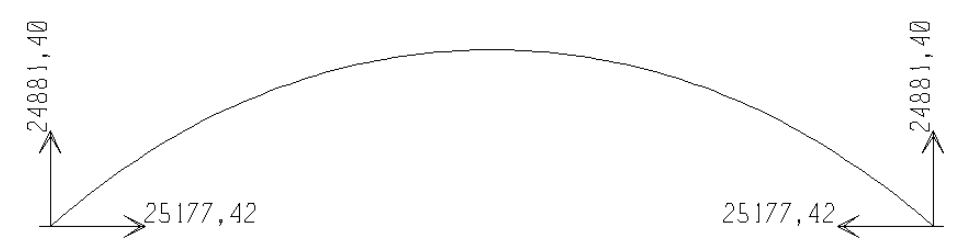

Slika 8 - Reakcije u ležajevima za $f=20 \mathrm{~m}[\mathrm{kN}]$ 

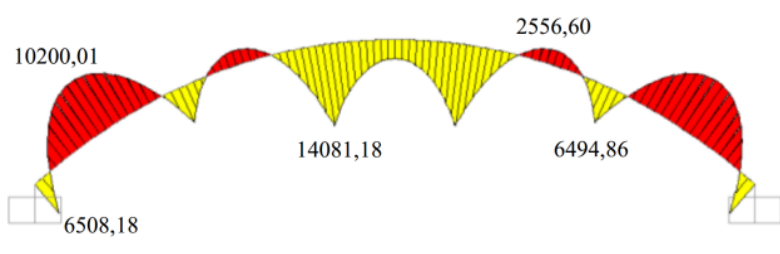

Slika 9 - Raspodjela momenata savijanja u luku $\mathrm{za} f=20 \mathrm{~m}[\mathrm{kNm}]$

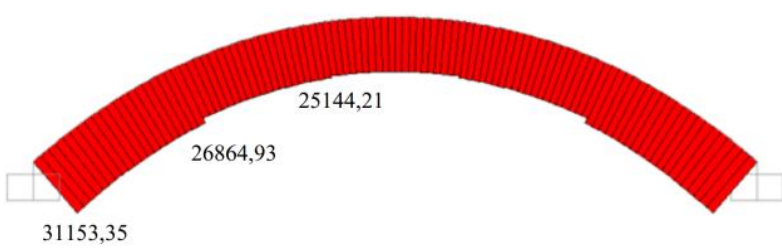

Slika 10 - Raspodjela uzdužne sile u luku $\mathrm{za} f=20 \mathrm{~m}[\mathrm{kN}]$

Svi rezultati proračuna upisani su u tablicu 5 . Unutarnje sile u luku (slika 11) pri ležaju (u peti luka) uz oznaku M i N (moment savijanja i uzdužna sila) imaju sufiks -ležaj, dok unutarnje sile u luku ispod stupa S3 imaju sufiks -luk. Vertikalna reakcija u ležaju ima oznaku $V$, a horizontalna $H$.

Nakon određivanja naprezanja u luku, posebno od momenta savijanja i posebno od uzdužne sile, izračunana su naprezanja u gornjem $\left(\boldsymbol{\sigma}_{2}\right)$ i donjem $\left(\sigma_{1}\right)$ rubu poprečnog presjeka luka tako da su im vrijednosti zbrajane, odnosno oduzimane.

Tablica 5 - Reakcije i unutarnje sile za različite strjelice luka

\begin{tabular}{|c|c|c|c|c|c|c|c|}
\hline $\begin{array}{c}f \\
{[\mathrm{~m}]}\end{array}$ & $\begin{array}{c}\text { V-ležaj } \\
{[\mathrm{kN}]}\end{array}$ & $\begin{array}{c}H \text {-ležaj } \\
{[\mathrm{kN}]}\end{array}$ & $\begin{array}{c}\text { Omjer } \\
\text { sila }\end{array}$ & $\begin{array}{c}\text { N-luk } \\
{[\mathrm{kN}]}\end{array}$ & $\begin{array}{c}M \text {-luk } \\
{[\mathrm{kNm}]}\end{array}$ & $\begin{array}{c}\text { N-ležaj } \\
{[\mathrm{kN}]}\end{array}$ & $\begin{array}{c}\text { M-ležaj } \\
{[\mathrm{kNm}]}\end{array}$ \\
\hline 10 & 23332,14 & 45638,83 & 1,96 & 46006,30 & 22711,12 & 48936,71 & $-18939,25$ \\
\hline 15 & 24069,61 & 32477,88 & 1,35 & 33006,80 & 16207,20 & 37102,89 & $-1112,77$ \\
\hline $\mathbf{2 0}$ & $\mathbf{2 4 8 8 1 , 4 0}$ & $\mathbf{2 5 1 7 7 , 4 2}$ & $\mathbf{1 , 0 1}$ & $\mathbf{2 5 8 6 1 , 9 1}$ & $\mathbf{1 4 0 8 1 , 1 7}$ & 31153,35 & $\mathbf{6 5 0 8 , 1 8}$ \\
\hline 25 & 25756,50 & 20626,02 & 1,25 & 21458,99 & 13358,71 & 27944,32 & 10744,05 \\
\hline 30 & 26680,07 & 17535,63 & 1,52 & 18509,43 & 13216,08 & 26168,06 & 13477,05 \\
\hline 35 & 27645,47 & 15309,37 & 1,81 & 16416,65 & 13357,71 & 25219,05 & 15405,52 \\
\hline 40 & 28642,77 & 13630,85 & 2,10 & 14864,27 & 13645,90 & 24776,66 & 16836,76 \\
\hline 45 & 29665,94 & 12322,02 & 2,41 & 13674,92 & 14022,68 & 24662,91 & 17942,36 \\
\hline 50 & 30711,08 & 11274,03 & 2,72 & 12740,10 & 14448,56 & 24772,09 & 18814,49 \\
\hline
\end{tabular}

Tablica 6 - Naprezanja za različite strjelice luka [N/mm²]

\begin{tabular}{|c|c|c|c|c|c|c|c|c|}
\hline $\begin{array}{c}f \\
{[\mathrm{~m}]}\end{array}$ & $\sigma$ M-luk & $\sigma$ N-luk & $\sigma_{1}$-luk & $\sigma_{2}$-luk & $\sigma$ M-ležaj & $\sigma$-ležaj & $\sigma_{1}$-ležaj & $\sigma_{2}$-ležaj \\
\hline 10 & 5,242 & 7,766 & 2,524 & 13,008 & 4,371 & 8,261 & 3,889 & 12,632 \\
\hline 15 & 3,741 & 5,572 & 1,831 & 9,312 & 0,257 & 6,263 & 6,006 & 6,520 \\
\hline 20 & 3,250 & 4,366 & $\mathbf{1 , 1 1 6}$ & $\mathbf{7 , 6 1 6}$ & $\mathbf{1 , 5 0 2}$ & $\mathbf{5 , 2 5 9}$ & $\mathbf{3}, 757$ & $\mathbf{6 , 7 6 1}$ \\
\hline 25 & 3,083 & 3,622 & 0,539 & 6,706 & 2,480 & 4,717 & 2,237 & 7,197 \\
\hline 30 & 3,050 & 3,124 & 0,074 & 6,175 & 3,111 & 4,417 & 1,307 & 7,528 \\
\hline 35 & 3,083 & 2,771 & $-0,312$ & 5,854 & 3,556 & 4,257 & 0,701 & 7,813 \\
\hline 40 & 3,150 & 2,509 & $-0,640$ & 5,659 & 3,886 & 4,182 & 0,296 & 8,068 \\
\hline 45 & 3,237 & 2,308 & $-0,928$ & 5,545 & 4,141 & 4,163 & 0,022 & 8,304 \\
\hline 50 & 3,335 & 2,151 & $-1,184$ & 5,485 & 4,343 & 4,182 & $-0,161$ & 8,524 \\
\hline
\end{tabular}

Analizom dobivenih rezultata kao najpovoljniji oblik osi luka određen je slučaj kada je strjelica luka $f=20 \mathrm{~m}$. Numeričkom analizom dobivene unutarnje sile u luku za $f=20 \mathrm{~m}$ su znatno manje nego za strjelice luka od $f=25 \mathrm{~m}$ do $f=50 \mathrm{~m}$. Ovo je jasno vidljivo iz tablica 5 i 6 te slika 11 i 12.

Najpovoljniju raspodjelu naprezanja (izražen tlak) ima slučaj kada je $f=10 \mathrm{~m}$, ali je horizontalna reakcija $80 \%$ veća od horizontalne reakcije za $f=20 \mathrm{~m}$, tako da je taj slučaj isključen iz daljnjeg razmatranja. 


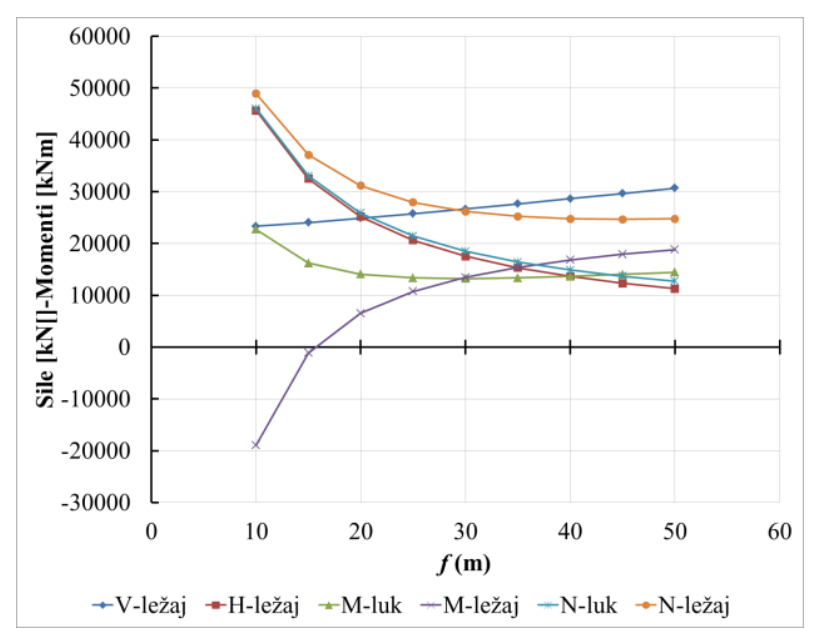

Slika 11 - Reakcije i unutarnje sile za različite strjelice luka

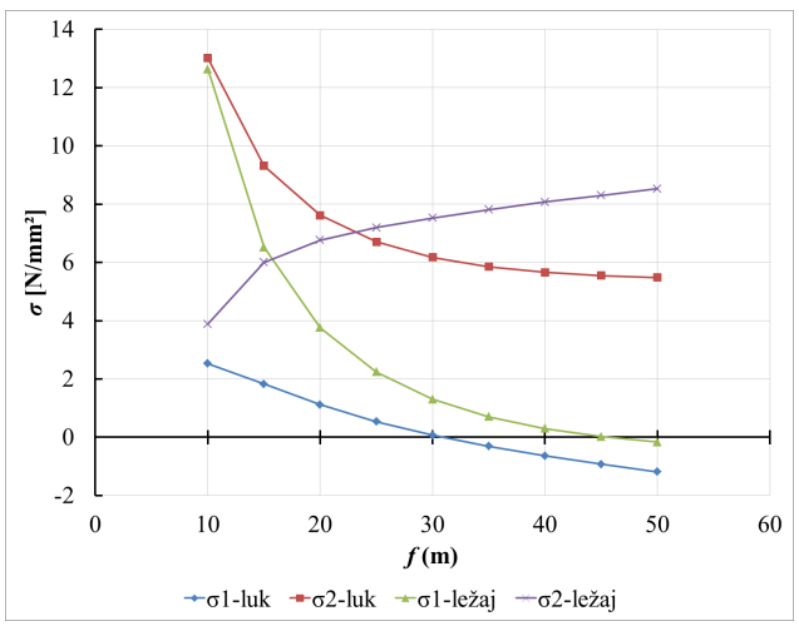

Slika 12 - Naprezanja u gornjem i donjem dijelu
poprečnog presjeka za različite strjelice luka

\section{Zaključak}

Lukovi, kao konstrukcijski sustavi, prikladni su za mostove velikih raspona, odnosno za mostove kod kojih dominira stalno opterećenje. Oblik luka je važan parametar pri dimenzioniranju lučnog mosta budući da on izravno utječe na ukupne horizontalne i vertikalne reakcije na osloncima te raspodjelu naprezanja u luku. Postupkom oblikovanja lučnog nosača mosta teži se u svakom poprečnom presjeku, zbog vanjskog opterećenja, osobito u slučaju stalnog opterećenja, uzdužne sile zadržati dominantno tlačnima te momente savijanja svesti na minimum. Svako odstupanje geometrije osi luka od tlačne linije dovodi do povećanja momenata savijanja, posebno u presjecima luka na mjestu unosa koncentrirane sile, odnosno ispod nadlučnih stupova. Kod kombinacije stalnog i prometnog opterećenja pojavit će se i vlačna naprezanja u presjeku, ali njih preuzima armatura.

Predstavljen je proračun najpovoljnijeg oblika osi luka mosta koji je oblikovan prema tlačnoj liniji dobivenoj za stalno opterećenje. Proračun oblika osi luka izrađen je za visine strjelice $f$ od 10 do $50 \mathrm{~m}$, u koracima od $5 \mathrm{~m}$. Iterativnim postupkom određen je najpovoljniji oblik luka sa strjelicom $f=20 \mathrm{~m}$. Rezultati analize reakcija na potporama za različite iznose strjelice luka pokazale su znatne promjene u vrijednostima reakcija.

Vidljiva je tendencija povećanja vertikalnih, a smanjenja horizontalnih reakcija s povećavanjem strjelice luka. Usporedbom omjera reakcija (veća sila podijeljena s manjom), tendencija je smanjenja omjera prema veličini strjelice $f=20 \mathrm{~m}$, gdje je omjer horizontalne i vertikalne reakcije jednak jedan.

\section{Literatura}

[1] Marić, Z.: Mostovi I, u Nastavni tekst na web stranici Fakulteta, 2009. (pristupljeno 18.04.2013.)

[2] Marić, Z.: Mostovi II, u Nastavni materijal na web stranici Fakulteta, 2009. (pristupljeno 18.04.2013.)

[3] Radić, J. i suradnici: Betonske konstrukcije - priručnik, Zagreb, Sveučilište u Zagrebu i ANDRIS, 2006.

[4] Radić, J.; Mandić, A.; Puž, G.: Konstruiranje mostova, Mostovi 2, Zagreb, Hrvatska sveučilišna naklada, 2005.

[5] Šram, S.: Gradnja mostova - Betonski mostovi, Zagreb, Golden marketing, 2002. 